Maria Christina D. Sio, MD

Jacqueline Austine U. Uy, MD

Ronaldo G. Soriano, MD

Department of Otolaryngology

Head and Neck Surgery

St. Luke's Medical Center
Correspondence: Dr. Ronaldo G. Soriano

Department of Otolaryngology

Head and Neck Surgery

St. Luke's Medical Center

279 E. Rodriguez Ave., Quezon City 1102

Philippines

Phone: (632) 7275543

Fax: (632) $7231199(\mathrm{H})$

Email: slmcearnosethroat@yahoo.com

Reprints will not be available from the author.

The authors declared that this represents original material that is not being considered for publication or has not been published or accepted for publication elsewhere in full or in part, in print or electronic media; that the manuscript has been read and approved by all the authors, that the requirements for authorship have been met by each authors, and that each author believes that the manuscript represents honest work.

Disclosures: The authors signed disclosures that there are no financial or other (including personal) relationships, intellectual passion, political or religious beliefs, and institutional affiliations that might lead to a conflict of interest.

Presented at Philippine Society of Otolaryngology- Head and Neck Surgery, Descriptive Research Contest (2nd Place), September 19, 2013, Natrapharm, The Patriot Bldg., KM 18 SLEX, Paranaque City.

\section{Calcifications in Thyroid Ultrasonography and Thyroid Carcinoma}

\begin{abstract}
Background: Thyroid nodules are a common disease entity occurring in $5-10 \%$ of the general population and increasing with age. Their detection on ultrasonography ranges from $13 \%$ to $67 \%$. Calcifications on ultrasound may occur in both benign and malignant diseases but have been cited for increased risk of thyroid carcinoma.
\end{abstract}

Objective: To determine the association of calcifications found on thyroid ultrasonography and the different types of calcifications with thyroid carcinoma.

\section{Methods:}

Design: Retrospective Study

Setting: Tertiary Private Hospital

Participants: 126 patients with pre-operative thyroid or neck ultrasonography who subsequently underwent thyroidectomy (total or subtotal, with or without frozen section) were selected from a database covering a one-year period from January to December 2012. The presence and type of calcification on ultrasonography was correlated with the final histopathologic report for a diagnosis of thyroid carcinoma. Sensitivity, specificity, positive and negative predictive values were obtained.

Results: 51 out of 126 studies (40\%) were observed to have calcifications of any description in both histologically benign (41\%) and malignant (59\%) nodules. Calcifications seen in malignancy arose from papillary carcinoma (86\%). Follicular carcinoma and others (Plasmacytoma and Lymphoma) accounted for $7 \%$ each. The peripheral type of calcification was most prevalent accounting for $37 \%$ ( 11 out of 30 ). The sensitivity of detecting calcifications on ultrasonography is $58.82 \%$, specificity $81.33 \%$, positive predictive value $68.18 \%$ and negative predictive value $74.38 \%$. Chi square test computed was $21.54(P<0.05)$.

Conclusion: There was an association between calcification found on ultrasonography and thyroid carcinoma and $86 \%$ of the calcifications were peripheral patterns mostly found in papillary thyroid carcinomas. Ultrasonography alone is not sufficient in diagnosing thyroid carcinoma but may increase the suspicion of malignancy depending on the type of calcification.

Keywords: Thyroid carcinoma, papillary carcinoma, calcifications, ultrasonography 
Thyroid nodules are common and occur in $5-10 \%$ of the general population with increasing age. 'They have a relative frequency of $4-7 \%$ by palpation alone and $13-67 \%$ by sonography. ${ }^{4}$ The incidence of thyroid nodular disease is quite high spontaneously occurring at a rate of $0.08 \%$ per year starting in early life and extending into the eighth decade. Although thyroid nodules represent a wide spectrum of disease, most are colloid nodules, adenomas, cysts and focal thyroiditis with only a few (5\%) being carcinoma. ${ }^{2}$

The most recent ATA guidelines for the evaluation of thyroid nodules and cancer emphasize the use of thyroid ultrasound to guide the clinician on which nodule requires biopsy to exclude malignancy. Microcalcifications are frequently cited with increased risk of thyroid malignancy specifically papillary thyroid carcinomas.?

Diagnosis of thyroid carcinoma includes a comprehensive history, physical examination and the aid of diagnostic tests. High-resolution ultrasonography is commonly used but frequently misperceived as unhelpful for identifying features that distinguish benign from malignant nodules. Although individual ultrasonographic findings may be of limited value, multiple signs of thyroid malignancy that appear in combination can make a more accurate prediction.

Calcifications on ultrasound may occur in both benign and malignant diseases. ${ }^{5}$ According to the literature, microcalcifications are one of the most specific ultrasound findings suggestive of a thyroid malignancy. ${ }^{3}$ Thyroid calcifications can be classified as microcalcification, coarse calcification or peripheral. ${ }^{3}$

Because most thyroid nodules are benign, calcifications may seem to appear more in benign nodules, thus being neglected by clinicians. This study aims to determine the association of calcifications found in thyroid or neck ultrasonography and of their types with thyroid carcinoma. This study will also determine the predictive value for malignancy of calcifications determined by thyroid ultrasonography.

\section{METHODS}

\section{Subjects}

This is a retrospective study analyzing 126 thyroidectomy patients selected from a database covering a one-year period between January to December 2012 at our institution. All patients included in the study underwent pre-operative thyroid or neck ultrasound in the same institution. Patients who underwent thyroidectomy where ultrasonography was done at a different institution were excluded.

All data was retrieved from the Healthcare Database System, which included official results of the procedures including the final histopathological report after each operation. Board-certified radiology and pathology consultants interpreted the ultrasonographic and histopathologic studies.

\section{Calcifications on Ultrasonography}

These studies were stored at the Picture Archiving and
Communication Systems (PACS) system and were reviewed using the BARCO Coronis Fusion 6 MegaPixel DL (MDCC-6130) system (Barco Pte Ltd, Singapore). Its technical specifications include the following: TFT AM Color LCD Dual Domain IPS-Pro, Native 6 MegaPixel 3280 x 2048 display, 654 x $409 \mathrm{~mm}$ active screen size and $800 \mathrm{~cd} / \mathrm{m} 2$ maximum luminance $(500 \mathrm{~cd} / \mathrm{m} 2$ DICOM calibrated).

Each ultrasound result had already been officially tandem-read by two radiology consultants (reader A) and then re-read by the co-author, a senior radiology resident (reader B) to ascertain the presence or absence of calcifications and to describe the types of calcifications with the reviewer blinded to the final histopathology.

Calcifications were defined as hyperechoic signals observed in the periphery or within a thyroid nodule or mass. Calcifications were further subdivided into (1) probably benign (inspissated colloid calcifications with typical reverberation artifacts) and (2) probably malignant. Subtypes of the latter include (2.a) microcalcifications (round laminar and punctate hyperechoic focus), (2.b) coarse (larger hyperechoic structures, either spicule or granular) and (2.c) peripheral (either rim or arc and further described as stippled, curvilinear smooth and irregular).

\section{Statistical Analysis}

A certified statistician at our institution then analyzed the data using Statistical Package for the Social Sciences SPSSv16.0 (IBM, New York, USA). Sensitivity, specificity, positive predictive and negative predictive values were then calculated.

\section{RESULTS}

Out of the 126 patients with thyroid mass who underwent ultrasonography, 17 were male, 109 female, with ages ranging from 10 to 73 years old (median age 45 ). There were 81 benign and 45 malignant final diagnoses by histopathology. Table 1 summarizes the findings.

Table 1. Summary of the histopathologic findings

\begin{tabular}{|l|c|}
\hline \multicolumn{1}{|c|}{ Benign } & Number of patients \\
\hline $\begin{array}{l}\text { Multiple Colloid Adenomatous Goiter } \\
\text { (MCAG) }\end{array}$ & 58 \\
\hline Follicular Adenoma & 4 \\
\hline Nodular Hyperplasia & 11 \\
\hline Hashimoto's Thyroiditis & 5 \\
\hline Tuberculosis & 1 \\
\hline Hurthle Cell Adenoma & 1 \\
\hline Unremarkable & 1 \\
\hline Total & 81 \\
\hline
\end{tabular}




\begin{tabular}{|l|c|}
\multicolumn{1}{|c|}{ Malignant } & Number of patients \\
\hline Papillary Carcinoma & 34 \\
\hline Papillary Microcarcinoma & 6 \\
\hline Follicular Carcinoma & 3 \\
\hline Hodgkin's Lymphoma & 1 \\
\hline Plasmacytoma & 1 \\
\hline Total & $\mathbf{4 5}$ \\
\hline
\end{tabular}

Of the 126 patients included, 51 studies (40\%) were observed to have calcifications of any description in both histologically benign and malignant nodules. Out of the 51 studies with calcifications, 30 (59\%) studies were seen in malignancies and $21(41 \%)$ in benign conditions. (Figure 1)

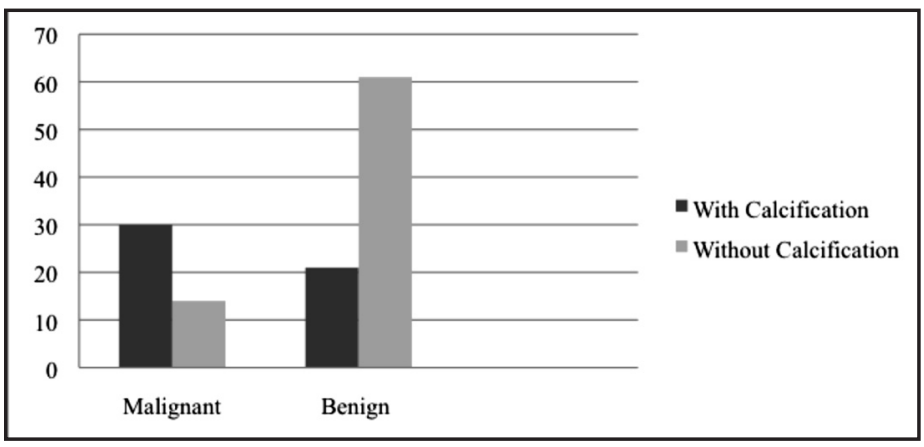

Figure 1. Breakdown of malignant and benign cases with and without calcifications

Majority of the calcifications in malignant cases were seen in those diagnosed with Papillary Carcinoma (26 out of 30 malignancies, 86\%). The rest were seen in Follicular Carcinoma ( 2 out of 30 malignancies, $7 \%$ ) and other cancers-- Hodgkin's lymphoma and Plasmacytoma (2 out of 30 malignancies, $7 \%$ ).

Calcifications secondary to inspissated colloid were described and all five examinations with this type of calcification were proven benign (multiple colloid adenomatous goiter). It should be noted that out of all the calcifications under the umbrella of malignant subtypes, there were more of the peripheral type of calcification seen in 37\% followed by microcalcifications $33 \%$ and lastly the coarse types which accounted for $30 \%$. (Figure 2)

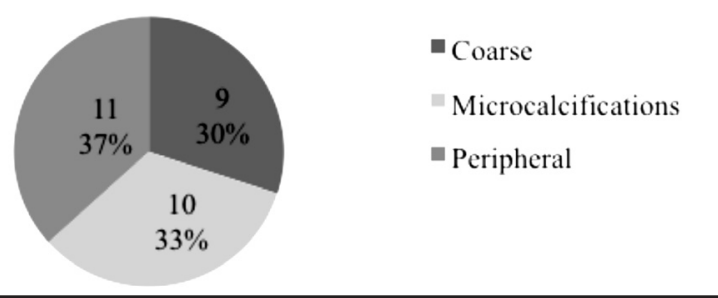

Figure 2. Types of calcifications seen in malignant cases
The studies reviewed by the co-author revealed reader disagreement in 14 studies or only $11 \%$. They differed in the types of calcification reported (ex. peripheral, coarse or microcalcification). The co-author based the description of the type of calcification reported from literature published by Hoang and his colleagues. ${ }^{3}$ These discrepant readings are listed in Table 2 with the final histopathology results.

Table 2. Reader discrepancy between Reader A and C0-author with final histopathology

\begin{tabular}{|c|c|c|c|}
\hline Reader A & $\begin{array}{c}\text { Reader B } \\
\text { (Co-author) }\end{array}$ & $\begin{array}{l}\text { Final } \\
\text { Histopathology }\end{array}$ & $\begin{array}{l}\text { Presence or } \\
\text { Absence of } \\
\text { Calcification }\end{array}$ \\
\hline Calcification & $\begin{array}{l}\text { Peripheral } \\
\text { calcification }\end{array}$ & $\begin{array}{l}\text { Papillary Thyroid } \\
\text { Carcinoma }\end{array}$ & Present \\
\hline Calcification & $\begin{array}{l}\text { Coarse } \\
\text { calcification }\end{array}$ & $\begin{array}{l}\text { Multiple Colloid } \\
\text { Adenomatous } \\
\text { Goiter }\end{array}$ & Present \\
\hline Calcification & $\begin{array}{l}\text { Peripheral } \\
\text { calcification }\end{array}$ & $\begin{array}{l}\text { Papillary Thyroid } \\
\text { Carcinoma }\end{array}$ & Present \\
\hline $\begin{array}{l}\text { Peripheral } \\
\text { Calcification }\end{array}$ & Microcalcification & $\begin{array}{l}\text { Multiple Colloid } \\
\text { Adenomatous } \\
\text { Goiter }\end{array}$ & Present \\
\hline $\begin{array}{l}\text { Peripheral } \\
\text { Calcifications }\end{array}$ & $\begin{array}{l}\text { Coarse } \\
\text { calcifications }\end{array}$ & $\begin{array}{l}\text { Multiple Colloid } \\
\text { Adenomatous } \\
\text { Goiter }\end{array}$ & Present \\
\hline $\begin{array}{l}\text { Peripheral } \\
\text { Calcifications }\end{array}$ & $\begin{array}{l}\text { Coarse } \\
\text { calcifications }\end{array}$ & $\begin{array}{l}\text { Multiple Colloid } \\
\text { Adenomatous } \\
\text { Goiter }\end{array}$ & Present \\
\hline Calcifications & Microcalcifications & $\begin{array}{l}\text { Papillary Thyroid } \\
\text { Carcinoma }\end{array}$ & Present \\
\hline Calcifications & $\begin{array}{l}\text { Coarse and } \\
\text { microcalcifications }\end{array}$ & $\begin{array}{l}\text { Multiple Colloid } \\
\text { Adenomatous } \\
\text { Goiter }\end{array}$ & Present \\
\hline Calcifications & $\begin{array}{l}\text { Coarse } \\
\text { microcalcifications }\end{array}$ & $\begin{array}{l}\text { Multiple Colloid } \\
\text { Adenomatous } \\
\text { Goiter with Nod- } \\
\text { ular Hyperplasia }\end{array}$ & Present \\
\hline Calcifications & $\begin{array}{l}\text { Coarse and } \\
\text { microcalcifications }\end{array}$ & $\begin{array}{l}\text { Multiple Colloid } \\
\text { Adenomatous } \\
\text { Goiter }\end{array}$ & Present \\
\hline Calcifications & Microcalcifications & $\begin{array}{l}\text { Multiple Colloid } \\
\text { Adenomatous } \\
\text { Goiter }\end{array}$ & Present \\
\hline Calcifications & $\begin{array}{l}\text { Coarse } \\
\text { calcifications }\end{array}$ & $\begin{array}{l}\text { Papillary Micro- } \\
\text { carcinoma }\end{array}$ & Present \\
\hline $\begin{array}{l}\text { Peripheral } \\
\text { calcifications }\end{array}$ & $\begin{array}{l}\text { Coarse } \\
\text { calcifications }\end{array}$ & $\begin{array}{l}\text { Multiple Colloid } \\
\text { Adenomatous } \\
\text { Goiter }\end{array}$ & Present \\
\hline Calcifications & $\begin{array}{l}\text { Coarse } \\
\text { calcifications }\end{array}$ & $\begin{array}{l}\text { Multiple Colloid } \\
\text { Adenomatous } \\
\text { Goiter }\end{array}$ & Present \\
\hline
\end{tabular}

The sensitivity of the type of calcification in predicting malignancy on ultrasonography was calculated to be $58.82 \%$, specificity was $81.33 \%$. On the other hand, predicting thyroid malignancy based on 
the type of calcification had a positive predictive value of $68.18 \%$ and negative predictive value of $74.39 \%$. (Table 3 )

Table 3. Statistical analyses of calcification found on ultrasonography

\begin{tabular}{|l|c|}
\multicolumn{1}{|c|}{ Parameter } & Percentage \\
\hline Sensitivity & $58.82 \%$ \\
\hline Specificity & $81.33 \%$ \\
\hline PPV & $68.18 \%$ \\
\hline NPV & $74.39 \%$ \\
\hline
\end{tabular}

Chi square test to determine the association of presence or absence of calcifications with benign and malignant disease was statistically significant at $21.54(P<0.05)$.

\section{DISCUSSION}

Calcifications detected on thyroid ultrasonography may appear coarse or dense as microcalcifications or peripheral rim-like. ${ }^{6}$ Among these, the microcalcification and coarse types are known to be associated with increased likelihood of malignancy. ${ }^{6}$ Based on the study by Hoang et al. in 2007, microcalcifications are found in $29 \%$ to $59 \%$ of all primary thyroid carcinomas, most commonly in papillary thyroid carcinoma. This subtype is one of the most specific features of thyroid malignancy with a specificity of $85.8 \%-95 \%$ and a positive predictive value of $41.8 \%-94.2 \% .^{3}$

In our study, there were more peripheral types of calcification at $33 \%$. Similar studies were published by Yoon et al. in 2007 and Park et al. in 2011 on peripheral calcification seen on ultrasonography, its pattern and association with thyroid malignancy.

On histopathology, thyroid calcifications are divided into psammomatous and dystrophic types. Psammomatous calcifications consist of laminated round calcium deposits in the epithelium which are formed in papillary thyroid carcinomas. These are detected as microcalcifications on ultrasonography. In contrast, dystrophic calcifications consist of non-laminated amorphous deposits in fibrous tissue septa. This type of calcification is thought to correspond to coarse calcifications on ultrasonography, which can occur in both benign and malignant conditions. Peripheral calcifications on the other hand, are patterns of dystrophic calcification located around nodules. They were generally thought to be more frequently associated with benign conditions but cases of papillary thyroid carcinoma associated with this type of calcification have been reported. ${ }^{6}$ The results of the this study are congruent with these reports.

Based on statistical analysis, the presence of calcification on thyroid ultrasound will yield a positive result 59\% of the time in patients with thyroid carcinoma. However, it will yield false positive results in 19\% of patients without thyroid carcinoma. On the other hand, the study tells us that $81 \%$ of patients who do not have thyroid carcinoma will test negative for the test (calcification on ultrasonography). Therefore a positive result from this means a high probability of the presence of the disease. Sixty-eight (68) \% of those with calcification detected on thyroid ultrasonography will actually have a thyroid carcinoma (whether papillary or follicular). Lastly, the probability of not having thyroid carcinoma given a negative thyroid ultrasound test is $74 \%$.

This study can guide clinicians in diagnosing thyroid nodules particularly in pre-operative evaluation and counseling patients and relatives. Ultrasound can help direct the biopsy toward areas of calcification with a high probability of disease. The limitation of this study is small sample size.

In conclusion, there was an association between calcifications found on ultrasonography and thyroid carcinoma and $86 \%$ of the calcifications were peripheral patterns mostly found in papillary thyroid carcinomas. Ultrasonography alone is not sufficient in diagnosing thyroid carcinoma but may increase the suspicion of malignancy depending on the type of calcification.

\section{REFERENCES}

1. Wang N, XuY, Ge C, Guo R, Guo K. Association of sonographically detected calcification with thyroid carcinoma. Head Neck. 2006 Dec; 28(12):1077-83.

2. Kakkos SK, Scopa CD, Chalmoukis AK, Karachalios DA, Spiliotis JD, Harkoftakis JG, et al. Relative risk of cancer in sonographically detected thyroid nodules with calcifications. J Clin Ultrasound. 2000 Sep; 28(7):347-52.

3. Hoang JK, Lee WK, Lee M, Johnson D, Farrell S. US Features of thyroid malignancy: pearls and pitfalls. Radiographics. 2007 May-Jun; 27(3):847-65.

4. Yunus, $M, A h m e d Z$. Significance of ultrasound features in predicting solid malignant thyroid nodules: need for fine needle aspiration. J Pak MedAssoc.2010 Oct; 60(10):848 53.

5. Rahman GA, Abdulkadir AY, Braimoh KT. Thyroid calcification: radiographic patterns and histological significance. AMA. 2008 Nov 18; 37:99-105

6. Yoon DY, Lee JW, Chang SK, Choi CS, Yun EJ, Seo YL, et al. Peripheral calcification in thyroid nodules, ultrasonographic features and prediction malignancy. J Ultrasound Med. 2007 Oct; 26(10):1349-55.

7. Lu Z, Mu Y, Zhu H, Luo Y, Kong Q, Duo J, et al. Clinical value of using ultrasound to assess calcification patterns in thyroid nodules. World J Surg. 2011 Mar; 23(3):14-5.

8. Khoo ML, Asa SL, Witterick IJ, Freeman JL. Thyroid calcification and its association with thyroid carcinoma. Head Neck. 2002 Jul; 24(7):651-655.

9. Taki S, Terahata S, Yamashita R, Kinuya K, Nobata K, Kakuda K, et al. Thyroid calcifications: sonographic patterns and incidence of cancer. Clin Imaging. 2004 SepOct; 28(5):368-371. 